Meta

Journal des traducteurs

Translators' Journal

\title{
A Translator's Travel
}

\section{Joaquim Mallafrè}

Volume 38, numéro 4, décembre 1993

Le $J e$ du traducteur

The $I$ of the Translator

URI : https://id.erudit.org/iderudit/003543ar

DOI : https://doi.org/10.7202/003543ar

Aller au sommaire du numéro

Éditeur(s)

Les Presses de l'Université de Montréal

ISSN

0026-0452 (imprimé)

Découvrir la revue

Citer cet article

Mallafrè, J. (1993). A Translator's Travel. Meta, 38(4), 615-620.

https://doi.org/10.7202/003543ar

\section{Résumé de l'article}

L'auteur explique certaines similitudes entre les langues et l'importance de savoir les reconnaître pour la traduction. 


\section{A TRANSLATOR'S TRAVEL}

JOAQUIM MALLAFRÈ

Spain

\section{Résumé \\ L'auteur explique certaines similitudes entre les langues et l'importance de savoir les reconnaître pour la traduction.}

I probably started translating because I did not know enough English to read Ulysses directly. Maybe it is so with translators sometimes, and they need to translate the books they like in order to understand and enjoy them fully.

It is common place to say that reading a book in its original form is the best thing to do, and translations are but a pale approach to the original work, if not high treason. Traduttore-traditore is a well known formula to express that.

I do not quite agree. Of course you must read the book in its original language if you can; that is, if you know not only the language very well, but its world, its connotations, the allusions the native reader knows or senses perfectly well at a first reading.

Besides, I am interested in Literature in general. How could I have enjoyed so many Greek, Latin, Russian, French, German, Italian books if they were not translated into a language I know? To appreciate all the subtelties and complexities of certain books, a good translation may be better than a poor reading of the original.

On the other hand, treason is not the danger of translation alone. It is a problem of communication in general, even among people speaking the same language. Tell somebody something and it will be unrecognizable when somebody else brings the same news back to you. In a interview I was asked about the difficulties of translating Joyce into Catalan. I said, among other things, that you had to think before finding equivalents for the several registers of language. In his books, slang, scientific or theological jargon could be found, together with echos of nursery rhymes and children's games. The following day I bought the paper where the interview was to be published. The heading read: "From now on, Catalan children will be able to read and enjoy Ulysses." And both the interviewer and I spoke the same language! Obviously, he did not know anything at all about Joyce and I was entirely misunderstood and betrayed as a translator would probably not have done.

We used to translate a lot at school and I don't think that was bad at all. Unfortunately, I would not dare write in French now, but since my secondary school time I have been able to understand French speaking people, to make myself understood and to read books in French. So, from my experience, those systems based on the translation of morceaux choisis were not so bad, after all, and some modern approaches to languages, better as they may be in some aspects, are wanting in translation.

I studied English later, when I went to England as an assistant teacher of Spanish in a grammar school. At the time, I could hardly speak their language, but having thirty children in a class sharpens your wits for survival. In order to learn a wide vocabulary and become more or less familiar with the syntax, I translated a lot: poems, prose, advertising. Translating plays was very interesting, too, because of the dialogues. My first translation worthy of such a name was Osborne's Look Back in Anger, and it was gratifying to find expressions, allusions or set phrases, faithful to the original, in my own language. It had 
to work well on stage. Listening to a translation or reading it aloud is always a good thing to do, for the sake of rhythm and sound and living words.

Another major fact must be mentioned. I was borned Catalan and Catalan was the everyday language of my family, of our neighbours, of the people in the street, in shops, etc. But under the Franco regime, it was no longer a language of culture. It was deprived of any official status, banned from many places, cinema, books, shows... And from the school, of course.

So I went to school, and then to a secondary school, and then to University, and Spanish was the language for anything really serious. I took my degree and was not aware of what I was about to lose. Catalan was, at best, a language from the heart, good for folklore, and old sweet songs of yore.

Recovering my own language was the most exciting experience in translating. Recovering it while $\mathbf{l}$ was remembering and enlarging it. And it is amazing how well I knew it in spite of all those years when it was not taken into consideration, not even by me. The language at home, in the streets, in the market, but also the language of tales and novels and other books in catalan, published before the Spanish Civil War, and easily found in many houses, had given me a sense of language that the Spanish school was not able to match. I liked Spanish, and I still do. I was lucky to learn it, but I should have learnt it as an addition to my own language, not as a substitution tending to suppress Catalan, as the policy was at the time. I had to learn Catalan grammar and the rules of writing I had not been taught at school, but this was easier than translating into Spanish. I knew standard Spanish, but not the varieties, dialects, registers, undertones, that I could sense in Catalan, which alone could help me in translating such writers for whom language is so rich and complex, as Joyce, Pinter, Beckett, or in going back to the long and flowery periods of the eighteenth century. Fielding and Sterne complete the bulk of my translations.

On the other hand there is a long tradition of translations into Catalan. The first documents in our language go back to the twelfth century and many of them are translations: from the Forum Iudicum, from homiletic books. In the fifteenth century Latin and Greek authors, as well as French or Italian - Dante, Petrarca -, were known through Catalan renderings. The literary and political revival of the nineteenth century took translation well into account, and more recentely Josep Carner, Carles Riba or J.M. de Sagarra, were deeply involved in translating. Pompeu Fabra, the main artificer of the normative grammar of Catalan, encouraged and did some translation himself. In Reus, my home town, there was - and there still is - a busy cultural activity. The Centre de Lectura, a private institution but open to the public, kept Catalan alive at a high level and translation was part of its activity. There I admired the translations from French and Italian writers, classical and modern, carried out by Bonaventura Vallespinosa.

Since 1969, when I translated Osborne's play I have not only been translating other books but drawing data of interest from them. Translating enables us to see language in a twofold direction. One sees the differences, the characteristics of several languages, as well as their similarities. Although the tradition in the Humboldt-Whorf-Sapir line sees languages as creating a particular world for themselves, translation tries to build a bridge between two languages. Both are meant to express a common world or, at least, a world which can be shared by people belonging to different cultures. This is especially true of Western culture, which is basically the same for us all. In any case, as mentionned above, the problems of translation are not so different from the problems of communication in general, even for people in the same country, among whom we find a different cultural level, several registers, geographical or social dialects, differences according to age, sex, beliefs, and so on. 
Therefore, we become aware of the peculiar Weltanschauung of a particular language, but also of the differences inside it. And on comparing, say, English and Catalan, we are able to see how far they are from each other, but, at the same time, we become aware of much of their common ground. And it is amazing to discover the similarities or even the literal renderings of the same reality. Apart from the ones arising from human nature, we have a common background in the classical-Jewish-Christian tradition, reinforced by Philosophy, Literature, Arts, Politics, History, which make us aware of many allusions, cross-references, dealings and common problems reflected in a novel or in a poem.

Popular expressions of folklore, such as nursery rhymes, proverbs or tales make clear both these and other links. On many occasions we shall try and find a pre-existing expression in our language for a given situation:

Walking round the garden

'Twas a teddy bear.

One step, two step...

Tickle you under there!

has its Catalan counterpart in:

Si vas a la carnissera,

no compris carn ni d'aquí,

ni d'aquí, d'aquí o d'aquí.

D'aqui, que n'hi ha un bon bocf!

(If you go to the butcher's don't buy meat from here, nor here, but from here, which is a better piece).

It may be important to refer to a bear or to a butcher, but what must not be left out at all is the tickling game, a universal theme which makes the rhyme meaningful.

We can find literal renderings, such as:

A burnt child dreads the fire.

Ein gebranntes Kind fürchtet das Feuer.

Brânt barn skyr elden.

They have a basically exact correspondence in the rendering of some Romance languages, even though the child and the fire have been changed into a cat and water:

Gat escaldat amb aigua tèbia en té prou.

Gato escaldado del agua fría huye.

Chat échaudé craint l' eau froide.

Literalism must be taken into account, though. And it is surprising to find:

Bis dat qui cilo dat.

Qui pega primer pega dos cops.

Qui donne vite donne deux fois.

Wer bald gibdt, der doppelt gibdt.

or:

si la Candelera plora, l'hivern és fora. Si la Candelera riu, el fred és viu.

Se a Candeia chora, está o inverno fora. Se a Candeira rir, está o inverno por vir.

La veille de la Chandeleur, l'hiver se passe ou prend vigueur.

Si piove o nevisca per Candelora, dell inverno siamo fora. Se é sole o solicello, siamo in mezzo al verno. 
Bells have played an important role in our life. For centuries people have been summoned to church, have been informed of the time of day, brought to marry, to feast, to rest or to die to the sound of them pealing. Babies have grown up swinging and cradled like a bell (or riding or listening to dandling songs) on their parents' knees. So we find lines common to several bell songs.

\author{
Bímbales-bàmbales, \\ les capanes de Riudoms. \\ Qui s'ha mort? El Pere Porc... \\ Baladín-baladan \\ la campana de Sant Jan. \\ Qui est mort? Jean le Porc... \\ Quién se ha muerto? Juan el Tuerto... \\ Chi é morto? Beccatorto... \\ Wer ist tot? Sparbrot...
}

These popular expressions give us some examples of how to translate. We see that sometimes we have a popular formula, already existing in our language, which is a literal rendering; sometimes, we have an equivalence, where the same meaning is expressed with different words. And as popular expressions have a typical structure, if we do not find a preexisting formula in our language, we can use its methods: a literal translation (or even not so literal sometimes), but using rhyme, rhythm, a transposition of words or a contrivance to create the impression of a popular saying.

It has been said that the language is there and the writer combines its words according to his or her style. But, no doubt, we all quote from other people, we all utter words and phrases and whole sentences already in use. Sometimes we recognize the quotation as belonging to such and such a writer or politician, sometimes we remember our father always having said it, sometimes we use many expressions without knowing where we learnt them, not even being aware that we ever learnt them at all. They may be just echoes of sentences heard long ago. But inside a language we go on repeating, varying or combining its possibilities. And all languages do the same.

So I think it's important to know how language operates at an anthropological level, where I have studied what I call the tribe language and the polis language.

The language of the tribe, with its established forms and set phrases, songs and rhymes, has a complex verbal system which helps human development. It is not a mere curiosity but is related to several stages of maturity and information:

1. Body and environment are perceived and brought to awareness of through several baby games, with the fingers, ring dances, dandling, skipping, action rhymes.

2. Language, from sound to meaning (or double meaning), from form to syntax, is exercised through tongue-twisters, puns, riddles, idioms, etc.

3. Observation and popular knowledge are widely represented by proverbs.

4. Spells and magic, survive in modern greetings or curses.

5. Tales and stories provide people with a world where they can let loose their imagination.

What I have called "polis" language (from the Greek, common background, along with Latin, of words such as urbanity, politics, civilization, which define Western culture) is shaped along the same roots, but projecting beyong one's tribe.

6. Knowledge of the body politic and of social organization gives rise to their own parcel of language, which people can quote and repeat. 
7. Special languages for science and technology.

8. Ideology is present in many a stock phrase we listen to, or read or learn every day.

9. Religion, as a belief or at a sociological level, not in its simplest forms but organized in a complex system - rooted in a Book, curiously enough - , is present in prayers, quotations and daily utterances.

10. Literature or, rather, a literary world which includes the cinema, the theatre, the opera, not as anonymous stories but with reference to a cultured urban society, has its own influence and gathers many expressions from the previous points.

11. School, and

12. The Mass media are the bridges from the polis to the tribe.

This may sound strange, at first sight. There might be a different approach and more or fewer points to attend to, but as a starting point, I found the division useful to look for an equivalent expression in Catalan when translating from English. It helped me to assign the expression to a certain field and set the tone of mine according to the register used. It is difficult sometimes: A literary expression (point 10) may have become a proverb no longer distinguishable from a popular saying (3). A former prayer (9) may be now used in a ring dance (1). A tale (5) perhaps only survives in a set phrase (2). But knowing how a writer uses some expressions, to what field he would assign them, what reference we have to find an equivalent for - all this is useful if we want to translate some linguistically complex books; Rabelais, Jan Potocki or Joyce use the words of their own language and society and combine them according to their personal view and style. A translator should try to know what they refer to. To grasp their full meaning it is necessary to define the boundaries in their works, where tribe and polis are interwoven, as they are in many verbal expressions of everyday life, spread by the school and the media.

The polis language, as far as it is more general among Western countries is thought to be more translatable. Tribe language, as belonging to a particular group with other characteristics, looks more difficult. But there are some anthropological universals, and human beings count on their fingers, know about their bodies, get used to their surroundings, must learn to speak, to foresee tempests and perhaps know how to get rid of them through words. They are also curious about tales, real or fantastic. And besides, they must learn many things by heart just to live in a modern city, or special jargons to find work. They can hardly avoid the messages sent by governments, they may be subjected to a church or to reading novels, listening to the radio, going to the cinema, or going to school. Language is always there to help with a cliché or a wise sentence. How does a writer use or change them? A writer's sentence may become itself a cliché or a model for other sentences, quoted or changed. It is useful for a translator to know this.

It is surprising to learn from a book by L. Eckenstein (Comparative Studies in Nursery Rhymes) that the popular name for an insect belonging to the genus Coccinella has in many languages a common allusion to a tale referring to the ladybird who found the keys of heaven, which Our Lady had lost. Marieta in Catalan, mariquilla in Spanish, Marienkäfer in German, have the same forgotten connotation. In French it also refers to deity: bête à bon Dieu. We even find the relation to a goddess in India, where it is called Indragopas.

Equivalences such as First catch your hare, Don't count your chickens before they are hatched, No disguis blat que no sigui al sac $i$ ben lligat may be related to the wellknown fable of the milkwoman who broke her jug of milk and her future prospects with it.

If in Catalan Una flor no fa estiu ("A flower doesn't make a summer"), Spanish, English and French refer to a swallow (which does not always appear at the same season: 
Una golondrina no hace verano, "A swallow doesn't make a summer", Une hirondelle ne fait pas le printemps, which is already found in Aristotle.

The Bible gives rise to popular expressions: "Do as you would be done by", El que no vulguis per a tu, no ho vulguis per a ningú (cp.: Math. 7,12; Luke, 6.31). "A bird told me", $M$ ' ho ha dit un moixonet (cp.: Ecclesiastes, 10.20)

Some aphorisms reflect literary ideas of an age: Shakespeare expressed in "Brevity is the soul of wit" what Gracián did in Lo bueno, si breve, dos veces bueno.

In papers or T.V. ads we can listen to expressions like Heartbreaker Donna Rice, Rebel with a cause, Sound and fury on the right, Chi beve Neri ne ribeve, Mi mamá me mima, Last tango in Milan, Bush beats about the bush, where advertising or news headlines are based on other previous expressions and mix plays on words into fashion, cinema, literature or politics. I bet you can find a lot of allusions to several points of tribe and polis if you open today's daily right now.

These I had to keep in mind when translating, without over doing their importance, though: they are only a part of translating grounds, the part which refers to the language to which the writer belongs, but we have still to see how he or she uses it, combines its words and creates a style of his or her own.

Translation has taught me not only to know and love my native tongue, but to realize that I belong to a wider country too, worldwide, where, after all, many given expressions reflect a common background in many deeply human aspects. 